Baijayanta Maiti, MD, $\mathrm{PhD}$

Robert C. Bucelli, MD, $\mathrm{PhD}$

Neurol Neuroimmunol Neuroinflammation 2014;1:e8; doi: 10.1212/ NXI.0000000000000008

\section{ATYPICAL CSF FINDINGS IN WEST NILE NEUROINVASIVE DISEASE: A DIAGNOSTIC AND THERAPEUTIC CONUNDRUM \\ OPEN}

West Nile virus (WNV) infections are typically asymptomatic. Less than $1 \%$ present with meningitis, encephalitis, myelitis, or acute flaccid paralysis, collectively coined West Nile neuroinvasive disease (WNND). ${ }^{1}$ In 2012, the most severe outbreak since 2003, there were 5,387 cases reported, of which 2,734 (51\%) were WNND, resulting in 243 deaths. ${ }^{2}$

Case report. A 59-year-old man presented in August 2012 with fever to $39.2^{\circ} \mathrm{C}$, bifrontal headache, and 3 days of proximal left leg weakness without sensory complaints. He denied travel, lived in an urban setting, and reported no tick/mosquito bites. Neurologic examination was notable only for proximal left leg weakness and left leg areflexia. There was no rash or lymphadenopathy. EMG-nerve conduction studies (NCS) showed evidence of an acute left lumbosacral radiculopathy, anterior horn cell disease, and/or plexopathy (figure, F). Lumbar spine/lumbosacral plexus MRI revealed diffuse nerve root enhancement (figure, A-D). Brain MRI was normal. CSF analysis showed 163 nucleated cells/ $\mu \mathrm{L}$ with $89 \%$ lymphocytes and $8 \%$ "atypical cells," later designated plasma cells by a hematopathologist, and a protein of $147 \mathrm{mg} / \mathrm{dL}$ (figure, E). WNV antibody testing was sent while tests for other infectious etiologies (Gram stain, aerobic and fungal cultures, cryptococcal antigen, herpes simplex virus, varicella-zoster virus, cytomegalovirus, HIV, and tuberculosis) returned negative. Lyme serologies were not checked and empiric antimicrobial therapy was not initiated. Flow cytometry showed a small lambdapredominant $\mathrm{CD} 19+$ B-cell population $(0.3 \%$ of total cells). Further workup for lymphoma showed a serum lactate dehydrogenase of 253 IU/L (normal 100-250 IU/L); however, serum creatine kinase was $825 \mathrm{IU} / \mathrm{L}$, suggesting a myogenic source. CSF on hospital day 12 once again showed a small population of $\mathrm{CD} 19 \mathrm{~B}$ cells, this time negative for surface light chains. The second CSF sample showed a markedly elevated protein of $1,011 \mathrm{mg} / \mathrm{dL}$ with 9 nucleated cells $/ \mu \mathrm{L}$ and a lymphocytic predominance (96\%) (figure, E). Full-body PET/CT and additional workup for underlying inflammatory, neoplastic, or metabolic processes were unremarkable.

Symptoms progressed, resulting in a flaccid left leg and new proximal right leg weakness. Repeat EMGNCS on hospital day 16 localized the lesion to the lumbosacral nerve roots and/or anterior horn cells (figure, F). At this point CSF testing for WNV was still pending. Although supportive care is the mainstay of therapy, a benefit of high-dose steroids in WNND has been reported. ${ }^{3}$ Given the progressive weakness with electrodiagnostic evidence of ongoing axon loss, he was started on empiric IV methylprednisolone. Nerve root biopsy was considered but never pursued given that WNV antibody testing was still pending. WNV immunoglobulin $\mathrm{M}$ in CSF returned positive on hospital day 24 and steroids were discontinued. There was no change in the patient's examination after steroids, and he developed no other sequelae of WNND. At follow-up 8 weeks later his examination was unchanged.

Discussion. While WNND was an initial differential diagnosis, we pursued an extensive workup to evaluate for other infectious, inflammatory, and neoplastic etiologies.

Prior analysis of CSF in 250 patients with WNND documented a mean CSF protein of 101 $\mathrm{mg} / \mathrm{dL}$ (range 32-295 mg/dL) in those with encephalitis, levels higher than those in patients with only meningitis. ${ }^{4}$ Although the same study reports an incremental increase in CSF protein on repeat examination in 33\% of patients, the exact figures are not published. CSF protein in poliomyelitis peaks around 2-3 weeks into the paralytic stage of the illness before eventually normalizing. While a similar temporal pattern was observed, the absolute amount of CSF protein was substantially higher in our case. ${ }^{5}$ Repeat CSF analysis 8 days after the first showed a protein of $1,011 \mathrm{mg} / \mathrm{dL}$, a value much higher than previously reported in WNND and other infectious motor neuronopathies such as poliomyelitis. This finding forced us to revisit our differential. The interim progression of weakness and considerable delay in WNV serology prompted a trial of steroids in this clinical quagmire, albeit with great hesitation. CSF serology returned positive 23 days after it was sent, confirming the diagnosis of WNND. In retrospect, this patient was the first case of WNND in Missouri during the 2012 outbreak. 
Figure Lumbar spine MRI obtained on hospital day 2 demonstrating nerve root enhancement and evolution of CSF and electrodiagnostic findings
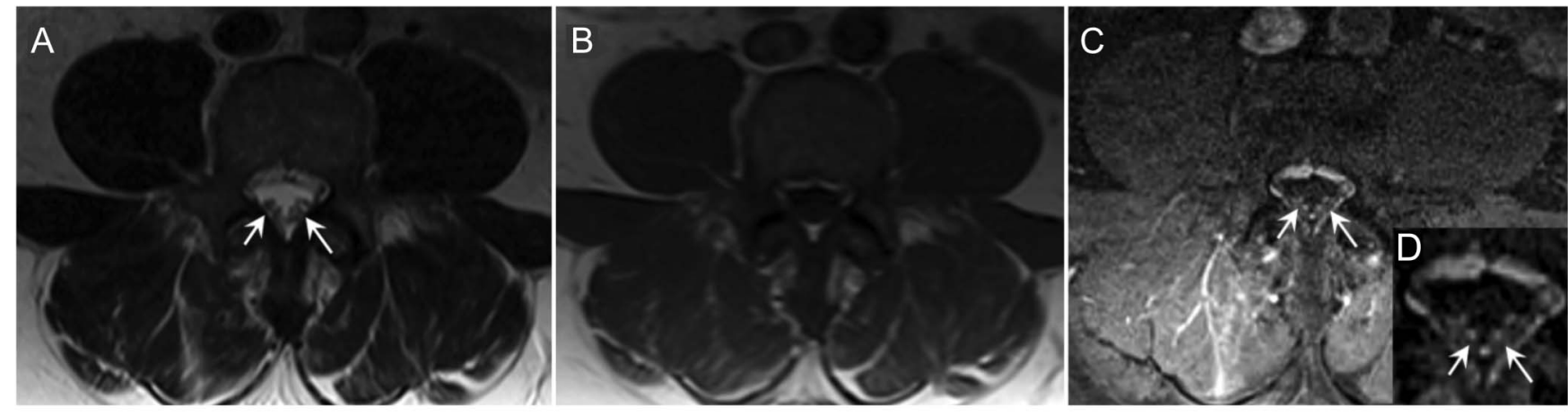

$\mathrm{E}$

\begin{tabular}{|c|c|c|c|}
\hline & $\begin{array}{c}\mathrm{NC} \\
\text { (cells } / \mu \mathrm{L})\end{array}$ & Protein (mg/dL) & $\begin{array}{l}\text { Glucose } \\
\text { (mg/dL) }\end{array}$ \\
\hline Day 4 & 163 & 147 & 55 \\
\hline Day 12 & 9 & 1,011 & 63 \\
\hline Case series ${ }^{4}$ & $226(1--7,950)$ & $101(32--295)$ & 71 \\
\hline
\end{tabular}

$\mathrm{F}$

Day 3

Day 16

\begin{tabular}{|l|c|c|}
\hline Left peroneal distal CMAP & $3.2 \mathrm{mV}$ & $0.7 \mathrm{mV}$ \\
\hline Left tibial distal CMAP & $4.2 \mathrm{mV}$ & $2.3 \mathrm{mV}$ \\
\hline Left sural SNAP & $3 \mu \mathrm{V}$ & $3 \mu \mathrm{V}$ \\
\hline EMG left tibialis anterior & No fibs/PSWs & $1+\mathrm{PSWs}$ \\
& Normal MUPs & Normal MUPs \\
& $\downarrow$ Recruitment & $\downarrow$ Recruitment \\
\hline EMG left gastrocnemius & No fibs/PSWs & $\uparrow$ Ins'l activity \\
& Normal MUPs & Normal MUPs \\
& $\downarrow$ Recruitment & $\downarrow$ Recruitment \\
\hline EMG left vastus medialis & No fibs/PSWs & $2+$ Fibs/PSWs \\
& Normal MUPs & Normal MUPs \\
& $\downarrow$ Recruitment & $\downarrow$ Recruitment \\
\hline EMG left iliopsoas & No fibs/PSWs & $3+$ Fibs/PSWs \\
& Normal MUPs & Normal MUPs \\
& $\downarrow$ Recruitment & $\downarrow$ Recruitment \\
\hline EMG left gluteus medius & No fibs/PSWs & $3+$ Fibs/PSWs \\
& Normal MUPs & Normal MUPs \\
& $\downarrow$ Recruitment & $\downarrow$ Recruitment \\
\hline EMG left L4 paraspinals & No fibs/PSWs & $2+$ Fibs/PSWs \\
\hline
\end{tabular}

(A) Axial T2-weighted image showing nerve roots (white arrows). (B) Axial T1-weighted image at the same level precontrast and (C) postcontrast showing gadolinium enhancement of nerve roots (white arrows). (D) Inset showing the nerve root enhancement at $2 \times$ magnification. (E) CSF analysis from days 4 and 12 demonstrating the marked increase in CSF protein between the 2 time points, much higher than values previously reported. (F) Pertinent findings from electrodiagnostic studies performed on hospital days 3 and 16 showing changes consistent with a lumbosacral polyradiculopathy vs anterior horn cell disease. CMAP = compound motor action potential; Fibs = fibrillation potentials; Ins'l = insertional; MUPs = motor unit potentials; NC = nucleated cells; PSWs = positive sharp waves; SNAP = sensory nerve action potential.

In conclusion, this case demonstrates that a markedly elevated CSF protein (in excess of $1 \mathrm{~g} / \mathrm{dL}$ ) can be observed in the setting of WNND. It also emphasizes how delays in critical test results can result in additional, sometimes unnecessary, diagnostic and therapeutic endeavors. Soon after this case, our institution switched the laboratory used for WNV testing, resulting in a drop in turnaround time from 2-3 weeks to $48-72$ hours for CSF and serum antibody results.
From the Department of Neurology, Washington University School of Medicine, St. Louis, MO.

Author contributions: Dr. Maiti contributed to the collection and interpretation of the data, the writing of the manuscript, and the preparation of the figure. Dr. Bucelli contributed to the collection and interpretation of the data, the writing of the manuscript, and the preparation of the figure. He also provided feedback and guidance to Dr. Maiti during the preparation of the manuscript.

Study funding: No targeted funding reported.

Disclosure: The authors report no disclosures relevant to the manuscript. Go to Neurology.org/nn for full disclosures. The Article Processing Charge was paid by the authors. 
This is an open access article distributed under the terms of the Creative Commons Attribution-Noncommercial No Derivative 3.0 License, which permits downloading and sharing the work provided it is properly cited. The work cannot be changed in any way or used commercially.

Received January 28, 2014. Accepted in final form April 15, 2014.

Correspondence to Dr. Bucelli: bucellir@neuro.wustl.edu

1. Davis LE, DeBiasi R, Goade DE, et al. West Nile virus neuroinvasive disease. Ann Neurol 2006;60:286-300.
2. Wilson MR. Emerging viral infections. Curr Opin Neurol 2013;26:301-306.

3. Pyrgos V, Younus F. High-dose steroids in the management of acute flaccid paralysis due to West Nile virus infection. Scand J Infect Dis 2004;36:509-512.

4. Tyler KL, Pape J, Goody RJ, Corkill M, KleinschmidtDeMasters BK. CSF findings in 250 patients with serologically confirmed West Nile virus meningitis and encephalitis. Neurology 2006;66:361-365.

5. Cumings JN. The cerebrospinal fluid in poliomyelitis. Postgrad Med J 1949;25:19-20. 


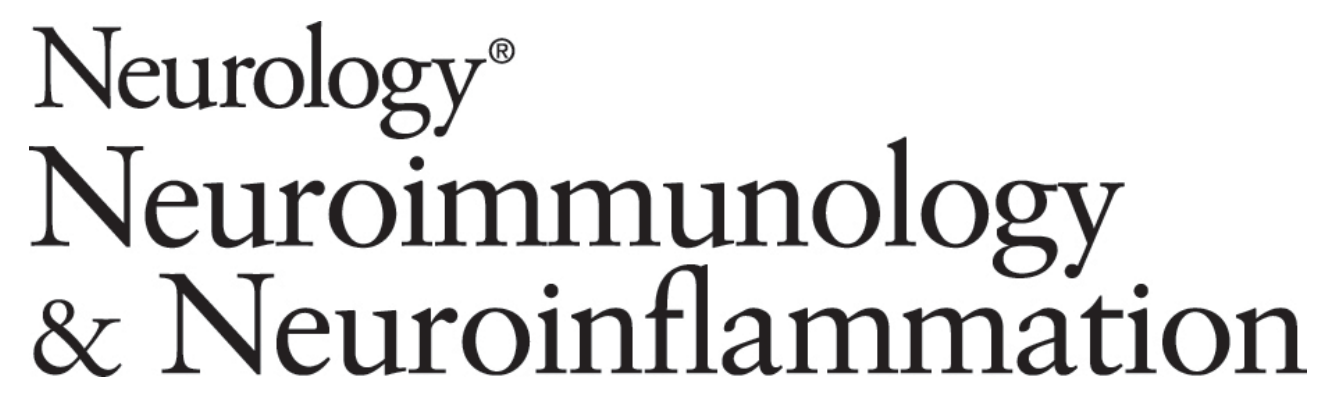

Atypical CSF findings in West Nile neuroinvasive disease: A diagnostic and therapeutic conundrum

Baijayanta Maiti and Robert C. Bucelli

Neurol Neuroimmunol Neuroinflamm 2014;1;

DOI 10.1212/NXI.0000000000000008

This information is current as of May 22, 2014

Neurol Neuroimmunol Neuroinflamm is an official journal of the American Academy of Neurology.

Published since April 2014, it is an open-access, online-only, continuous publication journal. Copyright $\odot$ 2014 American Academy of Neurology. All rights reserved. Online ISSN: 2332-7812.

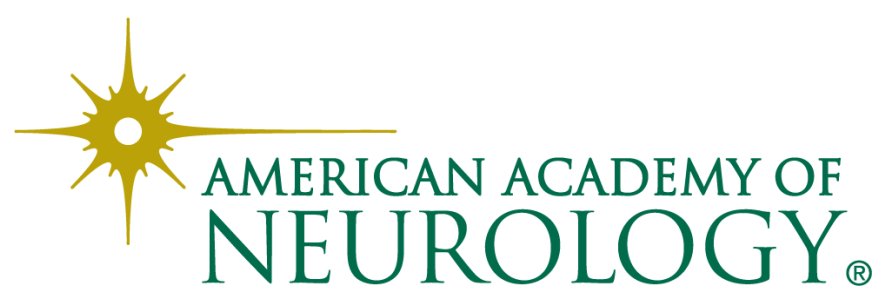




\section{Updated Information \& Services}

References

Citations

Subspecialty Collections

\section{Permissions \& Licensing}

Reprints including high resolution figures, can be found at: http://nn.neurology.org/content/1/1/e8.full.html

This article cites 5 articles, 1 of which you can access for free at: http://nn.neurology.org/content/1/1/e8.full.html\#\#ref-list-1

This article has been cited by 1 HighWire-hosted articles: http://nn.neurology.org/content/1/1/e8.full.html\#\#otherarticles

This article, along with others on similar topics, appears in the following collection(s):

\section{Anterior nerve cell disease}

http://nn.neurology.org//cgi/collection/anterior_nerve_cell_disease Cerebrospinal Fluid

http://nn.neurology.org//cgi/collection/cerebrospinal_fluid

\section{EMG}

http://nn.neurology.org//cgi/collection/emg

Viral infections

http://nn.neurology.org//cgi/collection/viral_infections

Information about reproducing this article in parts (figures,tables) or in its entirety can be found online at:

http://nn.neurology.org/misc/about.xhtml\#permissions

Information about ordering reprints can be found online: http://nn.neurology.org/misc/addir.xhtml\#reprintsus

Neurol Neuroimmunol Neuroinflamm is an official journal of the American Academy of Neurology.

Published since April 2014, it is an open-access, online-only, continuous publication journal. Copyright $\odot$ 2014 American Academy of Neurology. All rights reserved. Online ISSN: 2332-7812.

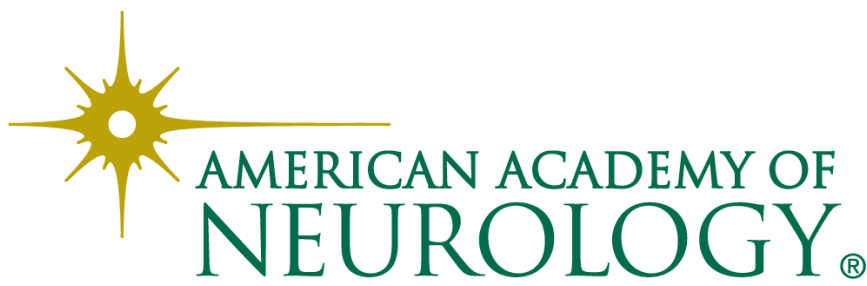

